\title{
非水カソード材料とアルミニウム不働態皮膜の ブレークダウン電圧
}

\author{
立 花 和 宏* \\ *山形大学 工学部(干992-8510 山形県米沢市城南 4-3-16)
}

\section{Breakdown Voltage of Aluminum Passivation Film with Non-aqueous Cathode}

\author{
Kazuhiro TACHIBANA*
}

\begin{abstract}
*Department of Chemistry \& Chemical Engineering, Yamagata University (4-3-16, Jonan, Yonezawa-shi, Yamagata 992-8510)
\end{abstract}

Keywords : Passivation Film, Breakdown Voltage, Non-aqueous Cathode, Aluminum, Valve Metal

\section{1. 緒言}

「あんまりぴったり直線にのったので自分でも信じられな いです。在学中にこんなきれいなデータにめぐり合えるなん て思いませんでした。」年間予算全部をつぎ込んで購入した わずかひとびんのイオン液体。その貴重な試薬を使って導電 率の対数とブレークダウン電圧の直線関係 (図 3 )を見出した とき，その実験に携わってくれた学生の口からでた言葉だっ た。

さて 1984 年に, 旭化成工業(侏)の実近健一および吉野彰を 発明人として出願されたひとつの特許があった ${ }^{1)}$ 。その特許 はコバルト酸リチウムを正極としたリチウムイオン二次電池 において, その集電体にアルミニウムが最適であることを開 示するものだった。この特許の中では明らかにされていない がリチウムイオン二次電池の正極集電体としてのアルミニウ ムは, 非水材料である有機電解液中で不働態化し耐食性を発 現するという重要な機能を担っていた。しかもその不働態皮 膜は電池のカソード材料との接触により絶縁性を失い, 集電 体としての機能も両立させていたのである。アルミニウムは リチウムイオン二次電池と同様に有機電解液を使う EDLC (電気二重層キャパシタ)でも集電体として活躍している。

一方, アルミニウムの不働態皮膜は, アルミニウム電解コ ンデンサの誘電体としても使われる。コンデンサの耐電圧が 高いとコンデンサを直列接続する必要が少なくなるため蓄え られるエネルギーが大きくなり, 部品点数を減らすことがで き, 装置の信頼性を向上と軽量化が期待できる。そのため電 解コンデンサの高耐電圧化と低内部抵抗を目指してさまざま な工夫がなされてきた。電解コンデンサの高耐電圧化とは高 い電圧でも誘電体の絶縁性を保つことであり，不働態皮膜の 耐電圧を高めることである。

このように不働態皮膜の絶縁性を理解することはリチウム イオン二次電池, EDLC, 電解コンデンサの設計をする上で
重要な意味を持つ。さてその不働態皮膜の絶縁性の尺度とし て残余電流やブレークダウン電圧が知られている。残余電流 は電流の観点から見た絶縁性で, 一定電圧を印加したときに わずかに流れる漏れ電流を言い, LC (Leak Current) と略さ れたりする。ブレークダウン電圧は電圧の観点から見た絶縁 性で, 一定電流を通電してアノード酸化できる最大電圧を言 い, 絶縁破壊電圧や火花電圧と呼ばれることもある。ブレー クダウン電圧は温度, 圧力, 溶液抵抗やアニオン濃度などに 依存することが知られている2)。また 1993 年に浦本は電解 蓄電器研究会において化成液中のシリカ微粒子がブレークダ ウン電圧を向上させることを報告し3)，2006 年には武田らが シリカオルガノゾルによる高耐圧アルミ電解コンデンサの開 発について報告している⿸广

一方電解コンデンサのカソード材料である電解液の水分は 使用温度条件に制限を加えるばかりでなく内部抵抗の上昇を 招くため, 早くからエチレングリコールやグリセリンが非水 材料として使用されてきた。しかし電解液中のわずかな水分 が不働態皮膜の自己修復に大きく寄与するため, 意図的に水 分を添加する場合もあった。電解液カソード材料の代わりに 固体カソード材料として検討された材料は二酸化マンガンな どの酸化物不定比半導体, $\operatorname{TCNQ}(7,7,8,8$-テトラシアノキ ノジメタン)などの有機半導体，ドーピングしたポリピロー ル, ポリチオフェン置換体, ポリジエトキシチオフェンなど の導電性高分子であった。しかし有機半導体や導電性高分子 をカソード材料に使った固体電解コンデンサの場合, アルミ ニウムのアノード酸化時の化成電圧に比べて電解コンデンサ としての耐電圧が著しく低下する5)。

これらのことはカソード材料によってアルミニウム不働態 皮膜の耐電圧が著しく変化することを意味しており, 特に有 機電解液や固体材料などの非水カソード材料においてその傾 向が顕著である。またアルミニウム不働態皮膜のブレークダ ウン現象の解明は電解コンデンサの高耐電圧化だけではなく 
リチウムイオン二次電池や EDLC の集電体アルミニウム上 での電解液の分解抑止や接触抵抗の低減などに有用な知見を 与える。本稿では，そのような背景を踏まえ非水カソード材 料とアルミニウム不働態皮膜のブレークダウン電圧について 筆者らが今までに明らかにしてきたことについて概説する。

\section{2. 有機電解液中におけるアルミニウムの不働態化}

アルミニウムはアジピン酸アンモニウムなどの水溶液中で アノード酸化したときち密なバリア型の不働態皮膜を生成す るバルブメタルとして知られている ${ }^{6)}$ 。一般に水溶液中にお けるアルミニウムのアノード酸化は次のような反応で進行し, $\mathrm{Al}_{2} \mathrm{O}_{3}$ の酸化皮膜を生成する。このときアルミニウムは溶媒 の水を酸化物イオンの供給源として不働態皮膜を生成する。

$2 \mathrm{Al}+3 \mathrm{H}_{2} \mathrm{O} \rightarrow \mathrm{Al}_{2} \mathrm{O}_{3}+6 \mathrm{H}^{+}+6 \mathrm{e}^{-}$

このようなアルミニウムをはじめとするバルブメタルのア ノード酸化に関する研究は古くからあり，それらの要点は不 働態皮膜中を横切るイオン電流密度 $j$ と皮膜に印加される高 電場 $e$ とが非線形な関係にあるということで, それに類し た理論は高電場機構と呼ばれている。そのもつとも典型的な 関係として(2)式を示したのが A. Gunterschulze と H. Betz であり, 1934 年のことである7)。

$$
j=A \exp B e \text {. }
$$

ここで $A, B$ は(2)式のパラメータである。パラメータとし てさらに $k$ を追加すると(2)式とファラデーの法則を組み合 わせることができる。ここで $k$ は成長速度と関係し, 生成 した金属酸化物のモル重量を密度と反応電子数抢よびファラ デー定数で除した值で，アノード酸化効率を $100 \%$ としたと きの電気量あたりで生成する単位面積あたりの皮膜の体積で ある ${ }^{8)}$ 。何らかの方法で不働態皮膜の密度が求まると $k$ の值 が定まり(2)式とファラデーの法則を使って $1 \mathrm{~V} / \mathrm{s}$ の電位上 昇速度を与える電場強度を求めることができる。この電場強 度は成長しつつある皮膜内部の電場強度であり，(2)式におい て急激に電流が増加する電場強度である。この電場強度の逆 数は電圧 $1 \mathrm{~V}$ あたり支えるのに必要な皮膜厚を意味し，ア ノダイジングレシオ $\delta$ と呼ばれる。水溶液系の場合，これ らのパラメータの值はおおよそ $A=2.6 \times 10^{-28} \mathrm{~A} \cdot \mathrm{m}^{-2}, B=$ $8.87 \times 10^{-8} \mathrm{~m} \cdot \mathrm{V}^{-1}, \quad k=5.7 \times 10^{-11} \mathrm{~m}^{3} \cdot \mathrm{C}^{-1}, \quad \delta=1.35 \times 10^{-9}$ $\mathrm{m} \cdot \mathrm{V}^{-1}$ である。

リチウムイオン二次電池や EDLC などに使われる有機電 解液は非水材料であり，水溶液とちがって酸化物を形成する ための酸化物イオンの供給源がない。有機電解液中で生成し た不働態皮膜を分析したところフッ素を多く含んでいた。さ て有機電解液中でのアルミニウムの不働態化は水溶液中同様 に高電場機構にしたがっていたが(図 1)，それらの速度論的 パラメー夕は水溶液中の值とは大きく異なる。 $1 \mathrm{M} \mathrm{LiBF}_{4}$ 系の場合，これらのパラメータの值はお打よそ $A=1.75 \times$ $10^{-11} \mathrm{~A} \cdot \mathrm{m}^{-2}, \quad B=4.71 \times 10^{-8} \mathrm{~m} \cdot \mathrm{V}^{-1}, \quad k=1.86 \times 10^{-10} \mathrm{~m}^{3}$ ・ $\mathrm{C}^{-1}, \delta=1.74 \times 10^{-9} \mathrm{~m} \cdot \mathrm{V}^{-1}$ である。 $1 \mathrm{M} \mathrm{LiPF}_{6}$ 系の場合, これらのパラメータの值は打抢よそ $A=0.88 \times 10^{-11} \mathrm{~A} \cdot \mathrm{m}^{-2}$, $B=4.75 \times 10^{-8} \mathrm{~m} \cdot \mathrm{V}^{-1}, \quad k=1.86 \times 10^{-10} \mathrm{~m}^{3} \cdot \mathrm{C}^{-1}, \quad \delta=1.71 \times$ $10^{-9} \mathrm{~m} \cdot \mathrm{V}^{-1}$ である。これらの有機電解液中でのパラメー夕 はアニオンの種類によらず似通っている。
またアルミニウムが非水材料で不働態化するのは $\mathrm{LiBF}_{4}$, $\mathrm{LiPF}_{6}$ ，などの電解質を用いたときに限定され，イミド塩な どでは不働態化しない。これらのことを考慮すると，アルミ ニウムは $\mathrm{LiBF}_{4}, \mathrm{LiPF}_{6},\left(\mathrm{C}_{2} \mathrm{H}_{5}\right)_{4} \mathrm{NBF}_{4}$ などのフッ素系ア ニオンからなる電解質を含む有機電解液中で, 次のようなバ リア型皮膜の生成反応により不働態化が進行し耐食性が与え られると考えられる。

$$
\begin{aligned}
& \mathrm{Al}+3 \mathrm{BF}_{4} \rightarrow \mathrm{AlF}_{3}+3 \mathrm{BF}_{3}+3 \mathrm{e}^{-} \\
& \mathrm{Al}+3 \mathrm{PF}_{6} \rightarrow \mathrm{AlF}_{3}+3 \mathrm{PF}_{5}+3 \mathrm{e}^{-}
\end{aligned}
$$

すなわち，水溶液中ではアルミニウムが溶媒と反応するのに 対し, 有機電解液中ではアルミニウムが溶解している電解質 アニオンと反応する。そして生成する不働態皮膜も水溶液中 で生成する $\mathrm{Al}_{2} \mathrm{O}_{3}$ からなる酸化皮膜とは異なり, 不働態皮 膜は $\mathrm{AlO}_{\mathrm{x} / 2} \mathrm{~F}_{3-\mathrm{x}}$ からなるフッ化物を主とする不定比化合物 である ${ }^{9)}$ 。そして有機電解液中の皮膜生成の速度論的パラ メータは, $\mathrm{BF}_{4}{ }^{-}, \mathrm{PF}_{6}{ }^{-}$にといったアニオンの種類の違いの 影響は少なく, $\mathrm{Al}_{2} \mathrm{O}_{3}$ か $\mathrm{AlF}_{3}$ かといった不働態皮膜の組成 の違いの影響が大きい。

非水溶媒中でのアルミニウムのブレークダウン電圧の挙動 として $\mathrm{LiBF}_{4}, \mathrm{LiPF}_{6},\left(\mathrm{C}_{2} \mathrm{H}_{5}\right)_{4} \mathrm{NBF}_{4}$ でのクロノポテン ショグラムを。図 1 に示す。アルミニウムに定電流を通電す ると水溶液中でアノード酸化した場合と同様に直線的な電位 上昇が確認されるが，その上昇速度は水溶液より急激である。 そしてある電位まで来ると電位上昇が停止する。参照電極の 電位が十分低いと仮定すれば，このアノード酸化できなくな る電位がブレークダウン電圧である。ブレークダウン電圧は

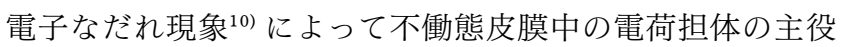
がイオンから電子に移行する電圧ととらえることもできる。 通常水溶液系のブレークダウン電圧は $600 \mathrm{~V}$ 程度とされてい るが，化皮膜を生成する有機電解液中のブレークダウン電圧 は $\mathrm{LiBF}_{4}$ で $38 \mathrm{~V}, \mathrm{LiPF}_{6}$ で $19 \mathrm{~V}$ と水溶液系よりかなり低い。 また $\left(\mathrm{C}_{2} \mathrm{H}_{5}\right)_{4} \mathrm{NBF}_{4}$ でわかるようにカチオンの種類はあまり 影響を与えない。

なおこのブレークダウン電圧は有機電解液中の水分濃度と ともに上昇する。 $1 \mathrm{M} \mathrm{LiBF}_{4}$ で徐々に水分を添加してゆくと $50 \mathrm{ppm}$ 以下では $38 \mathrm{~V}$ だったブレークダウン電圧が約 1200 $\mathrm{ppm}$ で $58 \mathrm{~V}$ となり，その後の水分増加に対しては頭打ちと なる ${ }^{11)}$ 。水溶液中の(1)式と異なり有機電解液中では(3)式ある

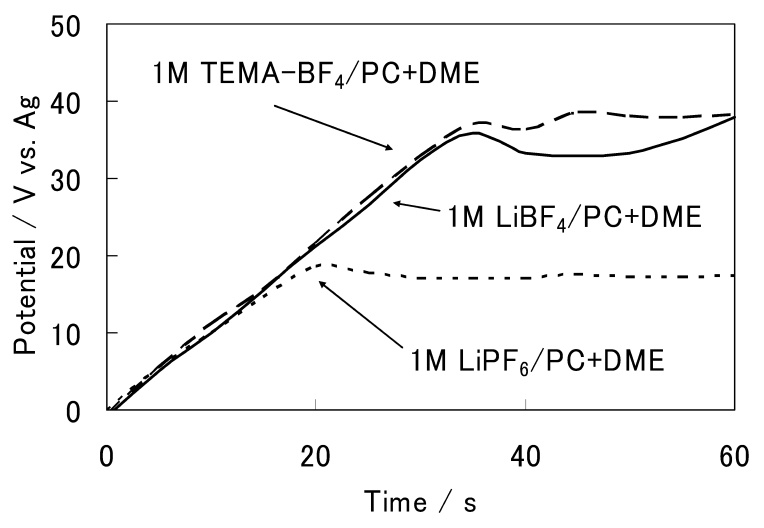

図 1 有機電解液中でのアルミニウムのクロノポテンショグラム (定電流 $1 \mathrm{~mA} \cdot \mathrm{cm}^{-2}$ ) 
いは(4)式のようにアルミニウムは溶質と反応する。したがっ てブレークダウン電圧を単純に電解質のアニオン濃度やモル 分率で議論すること ${ }^{12)}$ はむずかしい。しかし，有機電解液 の水分濃度が増加すると生成する皮膜に含まれる酸素の割合 も増加する傾向が見られることからブレークダウン電圧に皮 膜の組成が大きく関わっていると考えられる。またアルミニ ウムを定電圧に保持したときの残余電流は有機電解液中の水 分濃度とともに減少することからアルミニウム不働態皮膜の 残余電流が小さいほどブレークダウン電圧が大きくなる傾向 が伺える。

表 1 にアルミニウムと他のバルブメタルの有機電解液中で の分極挙動について比較検討した結果を示す。チタン, ジル コニウムはどのアニオンに対しても $4.6 \mathrm{~V}$ 付近で溶媒の酸化 分解が起こる。ブレークダウン電圧が電子なだれ現象によっ て不働態皮膜中の電荷担体の主役がイオンから電子に移行す る電圧と捉えれば，電子伝導性を有するチタン，ジルコニウ ムの不働態皮膜はブレークダウン電圧が極端に低い場合と解 釈することもできる。不働態皮膜のブレークダウンは有機電 解液の酸化劣化を引き起こすことになるため, リチウムイオ ン二次電池や EDLCのようにサイクル特性を求められるデ バイスではブレークダウン電圧の高いアルミニウムが適した 特性を備えていると言える。タンタル，ニオブは $\mathrm{BF}_{4}^{-}$, $\mathrm{PF}_{6}-$ に対して耐食性を持たずに腐食が進行する。 $\mathrm{ClO}_{4}^{-}$に 対して不働態化しているように見えるがブレークダウン電圧

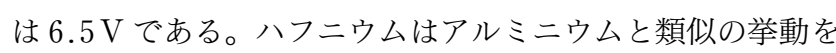
示した。アルミニウムは水分を含む $\mathrm{ClO}_{4}{ }^{-}$から遊離した塩 化物イオンで腐食が進行するが, それでも $\mathrm{ClO}_{4}{ }^{-}$に対して $21 \mathrm{~V}$ のブレークダウン電圧となる。そしてアルミニウムは $\mathrm{BF}_{4}{ }^{-}, \mathrm{PF}_{6}{ }^{-}$に対してそれぞれ $38 \mathrm{~V}, 19 \mathrm{~V}$ のブレークダウ ン電圧となる。このようにアルミニウムはフッ素を含む電解 液中でフッ化物を主成分とするち密なバリア型の不働態皮膜 を生成する他に例のない元素であることがわかった。

表 1 バルブメタルの有機電解液アニオンに対する反応 の種類

\begin{tabular}{|c|c|c|c|}
\hline & $\mathrm{BF}_{4}^{-}$ & $\mathrm{PF}_{6}^{-}$ & $\mathrm{ClO}_{4}^{-}$ \\
\hline \multirow{2}{*}{$\mathrm{Al}$} & (○不働態化 & (D)不働態化 & A腐食 \\
\hline & 38 & 19 & 21 \\
\hline \multirow{2}{*}{$\mathrm{Nb}$} & A腐食 & A腐食 & ○不働態化 \\
\hline & 3.2 & 3.8 & 6.5 \\
\hline \multirow{2}{*}{$\mathrm{Ta}$} & A腐食 & A腐食 & ○不働態化 \\
\hline & 3.0 & 4.0 & 6.5 \\
\hline \multirow{2}{*}{$\mathrm{Ti}$} & $\triangle$ 溶媒の分解 & $\triangle$ 溶媒の分解 & $\triangle$ 溶媒の分解 \\
\hline & 4.6 & 4.6 & 4.6 \\
\hline \multirow{2}{*}{$\mathrm{Zr}$} & $\triangle$ 溶媒の分解 & $\triangle$ 溶媒の分解 & $\triangle$ 溶媒の分解 \\
\hline & 4.6 & 4.6 & 4.6 \\
\hline \multirow{2}{*}{$\mathrm{Hf}$} & ○不働態化 & ○不働態化 & A腐食 \\
\hline & 8 & 8 & 3.5 \\
\hline
\end{tabular}

1）各金属毎の行の上段は反応の種類，下段は反応電圧 $[\mathrm{V}$ vs. $\left.\mathrm{Li} / \mathrm{Li}^{+}\right]$である

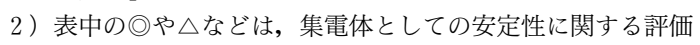
を示して抢り，(優れている) $\odot ， \bigcirc, \triangle, \triangle$ (劣る)の序列 になっている。
有機電解液同様に非水材料であるイオン液体中でのブレー

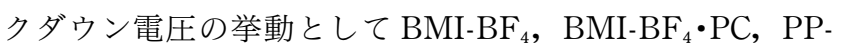
$\mathrm{BF}_{4}$ でのクロノポテンショグラムを図 2 に示す。イオン液 体はカチオンとアニオンのみからなり, 溶媒を含まない液体 である。そのイオン液体のひとつである $\mathrm{BMI}^{-\mathrm{BF}_{4} \text { 中におい }}$ て一定電流を通電するとアルミニウムの皮膜の成長にともな う電位上昇が見られる。この場合もフッ化物イオンを生成で きないアニオンを含む TFSI を用いると電位上昇が見られな くなる。また電位上昇速度が $\mathrm{LiBF}_{4}, \mathrm{LiPF}_{6},\left(\mathrm{C}_{2} \mathrm{H}_{5}\right)_{4}$ $\mathrm{NBF}_{4}$ などのフッ素系アニオンからなる電解質を含む有機電 解液と一致することから, イオン液体中においてもアルミニ ウムに生成している不働態皮膜はフッ化物を主とする不定比 化合物と考えられる。そしてそのブレークダウン電圧は 94 $\mathrm{V}$ にもなる ${ }^{13)}$ 。溶媒を含まないイオン液体の電解質のアニオ ン濃度は 0.5 であり, それが理論的上限である。したがって ブレークダウン電圧はアニオン濃度より導電率の方に依存し ているように見受けられる。この場合水溶液系と異なり生成 する不働態皮膜が酸化皮膜ではなくフッ化皮膜であることを あわせ考えると，アニオン濃度は不働態皮膜の組成に関与す るためブレークダウン電圧に影響を及ぼし, 不働態皮膜の組 成がほぼ同じであるならブレークダウン電圧は導電率に依存 すると考えられる。

水溶液系ではブレークダウン電圧と電解液の導電率の関係 が対数則に従うと言われている。そこで図 1 および図 2 から 求めた図 3 に抵抗率 $\rho$ (導電率の逆数)の対数とブレークダウ

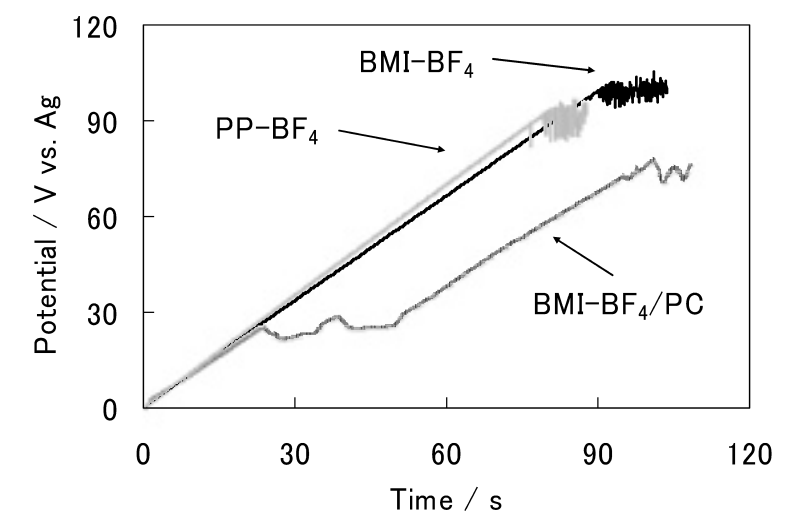

図2 イオン液体中でのアルミニウムのクロノポテンショグラム (定電流 $1 \mathrm{~mA} \cdot \mathrm{cm}^{-2}$ )

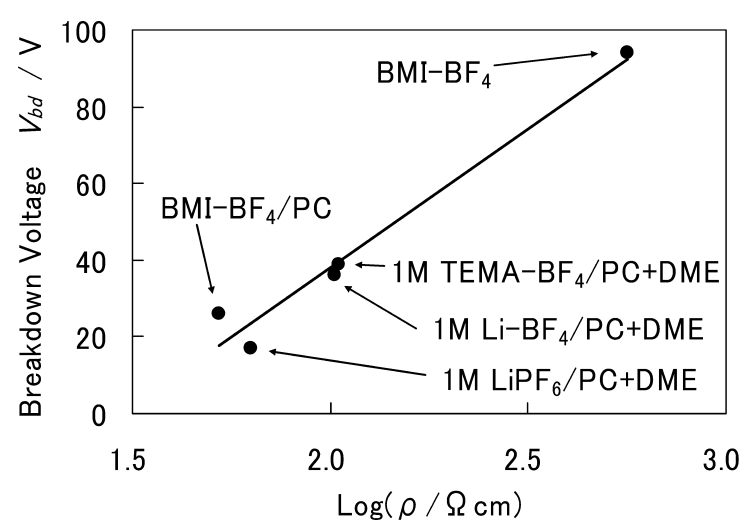

図 3 ブレークダウン電圧 $V_{b d}$ と電解液の比抵抗 $\rho$ の関係 
ン電圧 $V_{d b}$ の関係を示す。図 3 からわかるように非水材料 中におけるアノード酸化でもそのブレークダウン電圧は導電 率の対数にほぼ比例することがわかった。図 3 では $\mathrm{BF}_{4}^{-}$と $\mathrm{PF}_{6}$-の異なるアニオン種を使っているにも関わらずほぼ同 じ直線上にある。 $\mathrm{BF}_{4}^{-}$と $\mathrm{PF}_{6}{ }^{-}$のアニオン種はことなるも のの(2)式の皮膜生成パラメータはほぼ一致しており，このこ ともブレークダウン電圧がアニオン種よりも皮膜の組成に依 存することを示している。また，まったく溶媒を含まないイ オン液体においてもほほ同じ直線上にあり，このことはブ レークダウン電圧がアニオン濃度よりも導電率，すなわち皮 膜表面近傍の電場に依存することを示している。

\section{3. 固体非水カソード材料の接触と接触抵抗}

さて非水系でも水溶液系同様にアルミニウム表面の不働態 皮膜はブレークダウン電位があって，そこに至るまではほぼ 絶縁性を保っている。しかし，そこにたとえば炭素などの固 体カソード材料が接触するとアルミニウムの不働態皮膜は絶 縁性を失い導通が起きるようになる ${ }^{14)}$ 。また二酸化マンガン や一部の導電性高分子のような固体カソード材料では絶縁性 を失わないまでも，耐電圧が化成電圧に比べて大幅に小さく なる。このように固体非水カソード材料の接触が接触するこ とによってブレークダウン電位は大きく変化する。

たとえば，アルミニウム集電体にカーボンペーストのよう な炭素材料を塗布した電極を考える。この集電体と固体力 ソード材料からなる電極の構造の模式図を図 4 に示す。この ような炭素塗布電極は炭素表面の電気二重層容量を利用した EDLC 電極のひとつのモデルである。この場合は，集電体 表面の不働態皮膜の絶縁性は失われて電子伝導が起き，イオ ン電流よりも電子電流が支配的となって，炭素を通じて炭素 表面に電子が到達し，電気二重層が形成されていると考えら れる。前述のように不働態皮膜中の電荷担体の主役がイオン から電子に移行する電圧をブレークダウン電圧と解釈すれば, 炭素塗布電極に㧈いて集電体の不働態皮膜の絶縁性が失われ て電子伝導が発現している状態は，極めて低い電圧における ブレークダウン現象と捉えることもできる。すなわち炭素力 ソード材料を用いた場合の不働態皮膜／炭素界面のブレーク ダウン電圧は，不働態皮膜の接触抵抗による電圧降下に対応 すると考えられる。この集電体表面の不働態皮膜による接触 抵抗 $R$ は電気二重層容量 $C$ のハイレート充放電特性に大き な影響を与える。したがってアルミニウムのブレークダウン 現象の解明はEDLCの性能改善にも有用である可能性を示 唆している。
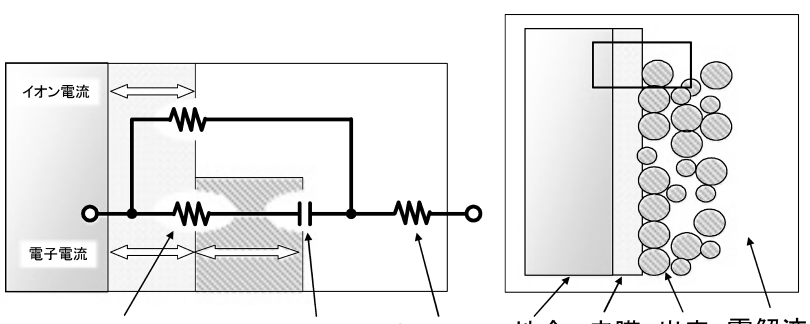

接触抵抗 $R^{\prime}$ 電気二重層容量 $C$ 溶液抵抗 $R^{\prime}$ 地金 皮膜 炭素 電解液

図 4 炭素接触時の不働態皮膜の絶縁性喪失と電気二重層の形成
図 5 にEDLCのサイクリックボルタモグラムのシミュ レーション結果を示す。シミュレーションは図 4 に示した電 子電流が支配的であると仮定して単純な $C$ と $R$ の直列等価 回路モデルで微分方程式を立てて表計算ソフトで数值計算し た。ここで静電容量 $C$ にはStern モデルを用いている ${ }^{16)}$ 容量の電位依存性を配慮した Stern モデルの方が平板モデル よりより実際に得られるデータに近いシミュレーションが得 られる。紙面の都合上, 計算やパラメータの詳細は別稿に譲 るが，図 5 に示したグラフは全て $0 \mathrm{~V}$ 付近に極小值を持つ $1200 \sim 2100 \mu \mathrm{F}$ の静電容量 $C$ を設定している。また直列抵 抗 $R$ は溶液抵抗，接触抵抗などからなる。ここで接触抵抗 には皮膜抵抗と集中抵抗が含まれるが15)，ここでは，それに 抵抗率が残余電流に依存する項をくわえたモデルを用いてい る。図 5 を見てわかるように直列抵抗 $R$ が大きくなるにつ れてボルタモグラム矩形から大きく歪み, 直線に漸近してく る。また抵抗率への残余電流の寄与率を高め, 抵抗 $R$ の最 小值と最大值の幅を広げると低電位側と高電位側での歪みの 具合が異なるようになる。

図 6 にそれぞれ予め $20 \mathrm{~V}$ 相当のアノード酸化皮膜をつけ たアルミニウム，ニオブ，タンタルにカーボンペーストを塗 布した炭素塗布電極のサイクリックボルタモグラムを示す。

図 5 で示したようにボルタモグラムが大きく歪むのは直列抵 抗成分 $R$ が大きいからである。アルミニウムでは典型的な

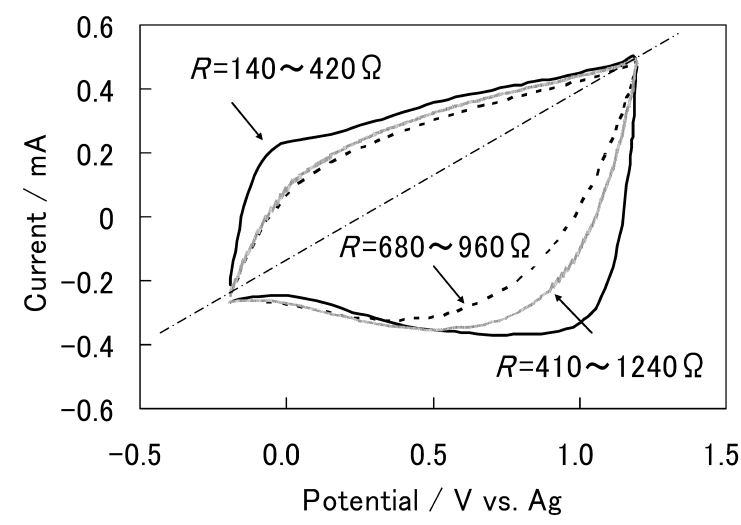

図 5 静電容量と抵抗の直列等価回路に基づく炭素塗布電極の齐 イクリックボルタモグラムのシミュレーション

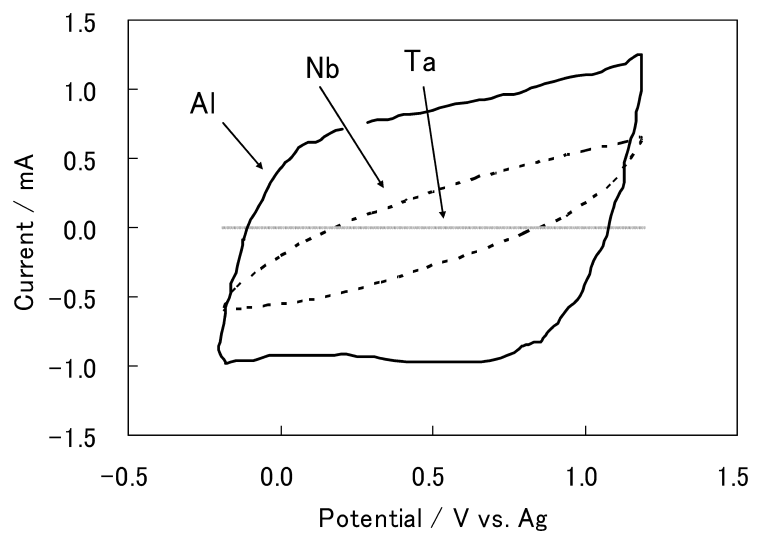

図 6 予め $20 \mathrm{~V}$ でアノード酸化したアルミニウム，二オブ，夕 ンタルを集電体に用いた炭素塗布電極のサイクリックボル タモグラム 


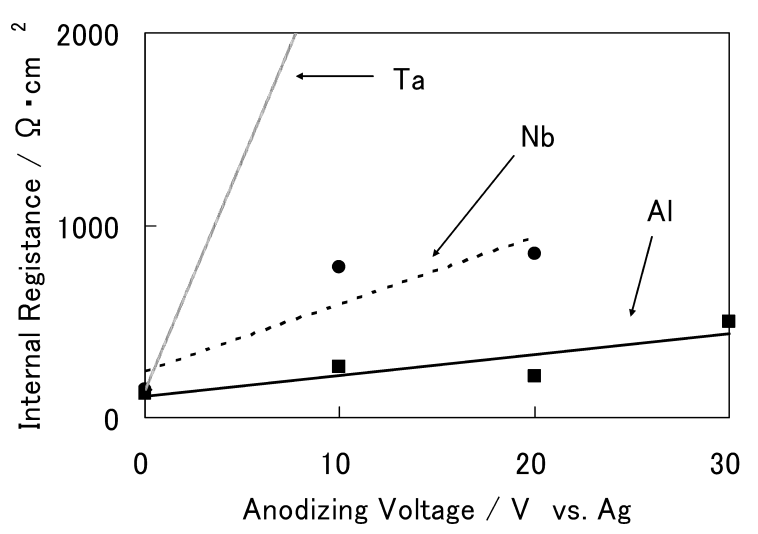

図7 予めアノード酸化したアルミニウム, 二オブ, タンタルを 集電体に用いた炭素塗布電極のサイクリックボルタモグラ ムから算出した接触抵抗とアノード酸化電圧との関係

箱型のボルタモグラムとなるが，ニオブでは皮膜抵抗が大き いためにボルタモグラムが大きく歪み, タンタルでは電流が ほとんど流れない。このように同じバルブメタルでも不働態 皮膜の表面欠陥の少ないタンタルで同様に炭素を接触させる とアルミニウムと違ってほとんど不働態皮膜の絶縁性が失わ れないことがわかる。このことは炭素材料がアルミニウムの 不働態皮膜の表面欠陥が顕在化することで不働態皮膜の絶縁 性が失われると考えられる。ここで考えている表面欠陥とは 形状欠陥 ${ }^{17)}$ ではなく, 不定比半導体に見られる酸素空孔の ような原子レベルでの欠陥である ${ }^{18)}$ 。それは導電助材に使わ れるサブミクロンクラスの微粒炭素よりも，ナノスケールの アルミニウムの不働態皮膜の厚みよりもずっと小さいと考え られる。さてこのような表面欠陥は表面電荷密度と関係する ため, 残余電流とも関係する。

図 7 には予め生成させる皮膜のアノード酸化の電圧を変え て不働態皮膜を生成させたアルミニウム，ニオブ，タンタル を集電体として炭素塗布電極とし, それらのサイクリックボ ルタモグラムと図 5 に示したシミュレーションの電流立ち上 がり部分を比較して算出した接触抵抗とアノード酸化電位と の関係である。不働態皮膜の厚みの増大とともに直列抵抗 $R$ が増大しており, 絶縁性を失った不働態皮膜が抵抗体の ように振る舞っていることがわかる。それと同時に，アルミ ニウム，二オブ，タンタルの順で直列抵抗 $R$ が増大してい る。それぞれの直線の傾きが異なることから, 直列抵抗 $R$ が不働態皮膜の厚みだけでなく, バルブメタルの種類, すな わち不働態皮膜の欠陥密度に依存していることが示唆される。

\section{4. 結言}

非水系液体 (有機電解液, イオン液体), 固体材料という非
水カソード材料をアルミニウムの不働態皮膜に接触させるこ とにより, ブレークダウン電圧が大きく変化したり不働態皮 膜はその絶縁性を失ったりする。ブレークダウン電圧は非水 カソード材料に含まれるアニオンの種類や濃度というょり, それによって生成する不働態皮膜の組成に大きく依存する。 非水系液体で生成する不働態皮膜の組成が同じフッ化皮膜で あれば,ブレークダウン電圧は非水系液体の導電率の対数と 直線関係にある。固体材料との接触抵抗をブレークダウン電 圧と関連付けてとらえることで, 不働態皮膜の欠陥密度が大 きいほど，すなわち残余電流が大きいほど接触抵抗が小さく なる傾向が示唆される。

(2007-3-22 受理)

\section{文献}

1 ）旭化成工業(侏, 特許公告平 04-052592（1992）.

2 ) 高橋英明, 坂入正敏, 島田英樹; 第 16 回 ARS 琵琶湖コンファ レンス予稿集, p. 41 (1999).

3 ）永田伊佐也; 電解液陰極アルミニウム電解コンデンサ, p. 289 (日本蓄電器工業(株), 1997).

4 ）武田政幸, 佐藤智洋, 宇恵 誠, 玉光賢治, 辻 達紀, 小澤 正；2006 年電気化学会秋季大会講演要旨集 p. 336（2006）。

5 ) 山本秀雄, 大島雅史; 第 16 回 ARS 琵琶湖コンファレンス予 稿集, p. 62 (1999).

6 ）清水健一, 幅崎浩樹, P. Skeldon, G. E. Thompson, and G.C. Wood；表面技術, 50, 2 (1999).

7 ) A. Gunterschulze and H. Betz ; Z. Phys., 92, 367 (1934).

8 ）馬場宣良；電解法による酸化皮膜, p. 17 （槓書店, 1996).

9 ）立花和宏, 佐藤幸裕, 仁科辰夫, 遠藤孝志, 松木健三, 小野幸 子; Electrochemistry, 69, 670 (2001).

10）相川孝作; 電子現象一電子物理と放電現象一, p. 173 （朝倉書 店, 1967).

11）立花和宏, 佐藤幸裕, 仁科辰夫, 遠藤孝志；2000 年電気化学会 秋季大会講演要旨集, p. 17 (2000).

12）加藤正義, 内田悦美, 工藤忠人；金属表面技術, 35, 474（1984）.

13）田中良樹, 立花和宏, 仁科辰夫, 遠藤孝志, 尾形健明; 表面技術 協会第 112 回講演大会講演要旨集, p. 199 (2005).

14）立花和宏, 高木泰彦, 仁科辰夫，松木健三 ; 表面技術協会第 98 回講演大会講演要旨集, p. 154 (1998).

15）表面技術協会編; 表面処理工学一基礎と応用一, p. 65（日刊 工業新聞社, 2000).

16）玉虫伶太；電気化学, p. 171 (東京化学同人, 1967).

17）立花和宏, 赤峰広規, 風間 晃, 仁科辰夫, 遠藤孝志, 尾形健 明; 表面技術協会第 112 回講演大会講演要旨集, p. 217 (2005).

18）齋藤安俊, 齋藤一弥; 金属酸化物のノンストイキオメトリー と電気伝導, p. 91 (内田老鶴圃, 1987). 